\title{
Energy and Reactivity Profile and Proton Affinity Analysis of Rimegepant with Special Reference to its Potential Activity against SARS-Cov-2 Virus Proteins using Molecular Dynamics
}

T Pooventhiran

St Berchmans College

Ephraim Felix Marondedze

University of Johannesburg

Penny Poomani Govender

University of Johannesburg

Utsab Bhattacharyya

St Berchmans College

D Jagadeeswara Rao

Dr Lankapalli Bullayya College

Elham S Aazam

King Abdulaziz University

Jinesh M Kuthanapillil

St Berchmans College

Tomlal Jose E

St Berchmans College

Renjith Thomas ( $\square$ renjith@sbcollege.ac.in )

St Berchmans College https://orcid.org/0000-0003-0011-633X

\section{Research Article}

Keywords: COVID, DFT, Rimegepant, Molecular Docking, Proton affinity, Molecular Dynamics

Posted Date: April 19th, 2021

DOl: https://doi.org/10.21203/rs.3.rs-283005/v1

License: (c) (1) This work is licensed under a Creative Commons Attribution 4.0 International License. Read Full License 


\section{Abstract}

Rimegepant is a new medicine developed for the management of chronic headache due to migraine. This manuscript is an attempt to study the various structural, physical and chemical properties of the molecules. The molecule was optimised using B3LYP functional with 6-311G+(2d,p) basis set. Excited state properties of the compound were studied using CAM-B3LYP functional with same basis sets using IEFPCM model in methanol for the implicit solvent atmosphere. The various electronic descriptors helped to identify the reactivity behaviour and stability. The compound is found to possess good nonlinear optical properties in gas phase. The various intramolecular electronic delocalisations and non-covalent interactions were analysed and explained. As the compound contain several heterocyclic nitrogen atoms, they have potential proton abstraction features, which was analysed energetically. The most important result from this study is from the molecular docking analysis which indicates that rimegepant binds irreversibly with three established SARS-CoV-2 proteins with ID 6LU7, 6M03 and 6W63 with docking scores $-9.2988,-8.3629$ and $-9.5421 \mathrm{kcal} / \mathrm{mol}$ respectively. Further assessment of docked complexes with molecular dynamics simulations revealed that hydrophobic interactions, water bridges and $\pi-\pi$ interactions play a signification role in stabilising the ligand within the binding region of respective proteins. MMGBSA free energies further demonstrated that rimegepant is more stable when complexed with 6LU7 among the selected PDB models. As the pharmacology and pharmacokinetics of this molecule are already established, rimegepant can be considered as an ideal candidate with potential for use in the treatment of COVID patients after clinical studies.

\section{Introduction}

Migrane is one of the major chromic disease affecting a large number of people throughout the globe [1]. Migraine reduces the quality of life, productivity, and limits the individual's participation in the social setup [2]. Usually, the migraine pain lasts between 4-72 hours, causes nausea, vomiting, irritation towards light and sometimes phonophobia [3]. The calcitonin gene-related peptide (CGRP) receptor was found to have a typical role in the onset of migrane and small drug molecules and antibodies are developed to antagonise this receptor [4,5]. Also, humanized antibodies against CGRP or its receptor are also being used as a prophylaxis measure in the management of migraine [6]. Rimegepant was developed as a CGRP receptor by using Heck reaction, Hayashi-Miyaura and Ellman reactions [7]. Rimegepant is a heterocyclic system where the cyclohexane ring system was designed with the help of Heck reaction. The other two reactions were used to design chiral centres with aryl and amine groups. This is a relatively new drug as it was marketed in 2020 as a small-molecule blockers of CGRP by the Biohaven Pharmaceuticals of New Haven, Connecticut [8].

SARS due to $\mathrm{n}-\mathrm{CoV}-2$ is at present considered as a global pandemic which affected the life and economy of all countries around the world $[9,10]$. Vaccines have been developed to prevent this viral attack, but only a small fraction of the entire global population is fortunate enough to get them [11-13]. Once infected, it may cause serious effect on patients leading to SARS pneumonia and ultimately death. Even though drug development against this deadly disease is a matter of importance, a new drug development 
is a time consuming process and hence, drug repurposing of existing drug molecules with known pharmacology and toxicity is a good idea. A lot of molecules are investigated as a probable candidate to treat the COVID related difficulties, but none of them is considered as a complete cure [14-20]. Computational methods has been extensively used for virtual screening and insilico screening of potential COVID-19 cures [21-23].

Remigepant is a newly marketed drug for the treatment of migraine. But its detailed electronic structure and reactivity is not reported elsewhere in best of our knowledge. We used density functional theory to establish the structure and properties of the molecule. Also, we evaluated the intramolecular electron delocalisations, non-covalent interactions and the average local ionisation energy indices of the molecule. Also, we wanted to check whether this new drug is a probable candidate for drug repurposing for the management of the COVID-19. Jiang and co-workers already showed that this molecule is a potential inhibitors targeting 2'-0-ribose methyltransferase of SARS-CoV-2 [24]. In this manuscript, we report the structure and electronic features of this molecule and also molecular docking and molecular dynamics study of the compound was performed with three other established COVID protein targets.

\section{Methods}

Rimegepant molecule was optimized with Gaussian-09 [25] software using DFT- B3LYP[26] functional and $6-311 \mathrm{G}+(2 \mathrm{~d}, \mathrm{p})$ as a basis set. This optimised structure was used to study FMO and NBO. TD-DFT with RCAM-B3LYP [27] functional was used to simulate UV spectra and was visualised using GaussSum [28]. Rimegepant molecule has more than two reaction sites for an example, 1,2-difluorophenyl-, cycloheptapyrimidinamine-, piperidine-1-carboxylate-, and 2H-imidazopyridin-2-one groups. Reaction sites of rimegepant calculated using Multiwavefunction [29] to prepare the electrostatic potential map [30], ALIE and noncovalent interactions [31]. Molecular docking was used to predict the binding affinity between the drug and different COVID associated proteins, which was downloaded from the RCSB [32]. The COVID-2 related proteins used in this study are PDBs: 6LU7, 6M03 and 6W63. The first one with ID 6LU7 represents the crystal structure of the main protease Mpro protein of the $\mathrm{n}-\mathrm{CoV}-2$ [33]. $6 \mathrm{MO} 3$ is the COVID-19 main protease in apo form [34] and 6W63 is SARS coronavirus papain-like protease [35] .Docking was performed using Autodock Vina [36, 37] and visualised using BIOVA Discovery studio [38] and was confirmed using molecular dynamics simulations.

Molecular dynamics simulations were executed using the GPU accelerated Desmond software accessed through Schrodinger 2020 release 3 hosted by the Lengau Linux Cluster of the Centre for High Performance Computing South Africa $[39,40]$. Prior to MD simulations, all models were downloaded from PDB and processed using the protein preparation wizard [40] available via the user interface Maestro version 12.5 [41]. Molecular dynamics simulation investigations were performed on undocked models (PDBs: 6LU7, 6M03 and 6W63) as well as their respective docked complexes for a timeframe of 400 nanoseconds. Prior to production, all systems were allowed to relax using the default conditions of DESMOND as given in Maestro. During the production stage, trajectories were recorded at 100 picoseconds intervals. As a result, 4004 frames were recorded. All simulations used a TIP5P solvent 
model in a $10 \AA$ orthorhombic box using OPLS3e as the force field [42]. Three sodium ions were added to both $6 \mathrm{M} 03$ and $6 \mathrm{~W} 63$ whereas two sodium ions were added to $6 \mathrm{LU} 7$ systems to neutralize the positive charge. An NPT ensemble utilizing 1 atm pressure and $300 \mathrm{~K}$ temperature was employed. Herein, the pressure and temperature were controlled using the Martyna-Tobias-KJein [43] and the Nose-Hoover chain thermostat methods respectively [43]. No restraints were applied and all the other parameters were kept at default. A cut-off of $9 \AA$ was used for short range Coulombic interactions. Post MD, various parameters such as protein - ligand interactions, root mean square deviation (RMSD) and root mean square fluctuation (RMSF), among others, were assessed. The Simulation Interaction Diagram tool available in Schrödinger Maestro was used for these parameters [41].

\section{Results And Discussions}

\subsection{Geometry for Rimegepant}

Rimegepant molecule structure was optimized by using density functional theory DFT-B3LYP as a method, and $6-311 \mathrm{G}+(2 \mathrm{~d}, \mathrm{p})$ as a basis set. Fig. 1 shows the structure of rimegepant molecule and explains by its important bond angles and distances. The bond angles are 117.4278 and $118.7913^{0}$ for 1F-30C-2F-35C-30C respectively, and their bond distances are 1.3556, 1.3524 and $1.3679 \AA$ for $1 \mathrm{~F}-30 \mathrm{C}$, $2 \mathrm{~F}-35 \mathrm{C}$ and $30-25 \mathrm{C}$ respectively. The bond distances for $30-21 \mathrm{C}, 4 \mathrm{O}-25 \mathrm{C}, 6 \mathrm{~N}-25 \mathrm{C}, 6 \mathrm{~N}-18 \mathrm{C}$ and $6 \mathrm{~N}-19 \mathrm{C}$ having $1.4679,1.2225,1.3687,1.4643$ and $1.4631 \AA$ respectively, and their bond angles for 21C-30-25C, 30-25C-40, 40-25C-6N, 18C-6N-25C and 19C-6N-25C partaking 115.7344, 123.2764, 124.4281, 118.5318 and $124.8133^{0}$ respectively. The bond angles are $124.2606,126.1067,127.4362,127.1117,111.0334$, 127.1832 and $114.8730^{\circ}$ for $12 \mathrm{C}-7 \mathrm{~N}-27 \mathrm{C}, 12 \mathrm{C}-7 \mathrm{~N}-26 \mathrm{C}, 50-27 \mathrm{C}-7 \mathrm{~N}, 5 \mathrm{O}-27 \mathrm{C}-10 \mathrm{~N}, 27 \mathrm{C}-10 \mathrm{~N}-29 \mathrm{C}, 10 \mathrm{~N}-29 \mathrm{C}-$ $11 \mathrm{~N}$ and $29 \mathrm{C}-11 \mathrm{~N}-39 \mathrm{C}$ respectively, and bond distances for $7 \mathrm{~N}-12 \mathrm{C}, 7 \mathrm{~N}-27 \mathrm{C}, 7 \mathrm{~N}-26 \mathrm{C}, 50-27 \mathrm{C}, 10 \mathrm{~N}-27 \mathrm{C}$, $10 \mathrm{~N}-29 \mathrm{C}, 11 \mathrm{~N}-29 \mathrm{C}$ and $11 \mathrm{~N}-39 \mathrm{C}$ are $1.4683,1.4028,1.3943,1.2226,1.3934,1.3832,1.3190$ and $1.3509 \AA$ respectively. The bond angles for $17 \mathrm{C}-8 \mathrm{~N}-56 \mathrm{H}, 17 \mathrm{C}-8 \mathrm{~N}-57 \mathrm{H}$ and $23 \mathrm{C}-9 \mathrm{~N}-34 \mathrm{C}$ having $109.5901,109.9474^{0}$ respectively, and the bond distances are 1.4778, 1.0190, 1.0187, 1.3455, 1.3364, 1.5227 and 1,5323 for $8 \mathrm{~N}-17 \mathrm{C}, 8 \mathrm{~N}-56 \mathrm{H}, 8 \mathrm{~N}-57 \mathrm{H}, 9 \mathrm{~N}-23 \mathrm{C}, 9 \mathrm{~N}-34 \mathrm{C}, 21 \mathrm{C}-23 \mathrm{C}$ and $20 \mathrm{C}-21 \mathrm{C}$ respectively.

\subsection{Frontier molecular orbital (FMO) properties for Rimegepant}

Rimegepant molecule structure was optimized by using density functional theory DFT-B3LYP as a method, and $6-311 \mathrm{G}+(2 \mathrm{~d}, \mathrm{p})$ as a basis set. The frontier molecular orbitals are mostly involved in reactions and explain the reactivity features of rimegepant [30,44-47]. Frontier molecular orbital data can be effectively used to study several reactivity information. Table 1 explains those important chemical descriptors. The frontier molecular orbitals are higher occupied molecular orbital (HOMO) and lower unoccupied molecular orbital (LUMO) energies are -6.5 and $-1.14 \mathrm{eV}$ respectively, and the energy gap between them is $5.36 \mathrm{eV}$. The gap is very high that the compound will be remain as an organic insulator. The gas phase ionization energy [48,49] and electron affinity [49] are are 6.5 and $1.14 \mathrm{eV}$ respectively. The global hardness and softness energies for rimegepant are 2.68 and 0.37 respectively. The chemical potential [48], electronegativity [30], electrophilicity index [50-53] and nucleophilicity index [54]for 
rimegepant are $-3.82,3.82,2.73$, and $0.37 \mathrm{eV}$, which indicates that the molecule is potentially reactive towards biological molecules. The calculated hardness and softness values are 2.68 and 0.37 [55-61].

Table 1 Frontier molecular orbitals properties for Rimegepant

\begin{tabular}{|ll|}
\hline Chemical descriptors & Energy in eV \\
\hline $\mathrm{E}(\mathrm{HOMO})$ & -6.50 \\
\hline $\mathrm{E}($ LUMO) & -1.14 \\
\hline Energy Gap $\Delta \mathrm{E}$ & 5.36 \\
\hline Ionization Energy & 6.50 \\
\hline Electron Affinity & 1.14 \\
\hline Global Hardness & 2.68 \\
\hline Global Softness & 0.37 \\
\hline Chemical Potential & -3.82 \\
\hline Electronegativity & 3.82 \\
\hline Electrophilicity index & 2.73 \\
\hline Nucleophilicity index & 0.37 \\
\hline
\end{tabular}

\subsection{TD-DFT study for Rimegepant in methanol}

Rimegepant molecule structure was optimized by using time dependent density functional theory RCAMB3LYP as a method, $6-311 \mathrm{G}+(2 \mathrm{~d}, \mathrm{p})$ as a basic set and methanol using as a solvent using IEFPCM solvation model [35-37]. Fig. 2 shows the UV-visible spectrum and Fig.3 shows the orbitals involved in which the electronic transitions. From the Fig. 2 shows, the peak appears at the wavelength is $260.05 \mathrm{~nm}$ and the oscillator strength is 03082 . From the Fig. 3 shows the important orbitals that participate in electronic transition. The major peak was due to the transition of electrons froms from higher occupied molecular orbital (HOMO) to first lower unoccupied molecular orbital (LUMO+1) which are located at $2 \mathrm{H}-$ imidazopyridin-2-one group to cycloheptapyridinamine group respectively with 91 percentage transition contribution.

\subsection{Nature bonding orbital (NBO) property for Rimegepant}

Intramolecular electron delocalisations due to hyper conjugation is very important for the stabilisation of a molecule. Natural bond orbitals can be used as an ideal method for the evaluation of these type of interactions. NBO 3.1 suite [38] associated with Gaussian09 W program was used to perform these calculations. The orbital occupancy and delocalisation energy data helps to analyse the different electron shifting. Both bonding and anti-bonding orbitals for rimegepant can give details in this part by transfer of 
electrons having suitable occupancies, from bonding, lone pairs and anti-bonding orbitals to anti-bonding orbitals with absorbing some energy.

The bonding electrons transfer from donor bonding orbitals to acceptor anti-bonding orbitals with their occupancies with suitable energies. From $\sigma$ (N9-C23) with the occupancy 1.7135 to $\sigma^{\star}$ (C22-C28) and $\sigma^{\star}$ (C33-C34) with delocalisation energies 13.63 and $25.61 \mathrm{kcal} / \mathrm{mol}$ respectively. From $\sigma$ (N11-C29) with occupancy 1.7448 to $\sigma^{\star}$ (C26-C32) and $\sigma^{\star}$ (C37-C39) using the energies are 11.26 and 23.11, from $\sigma$ (C22-C28) having the occupancy, is 1.6318 to $\sigma^{\star}$ (C31-C36) and $\sigma^{\star}$ (C33-C34) with the energies are 26.78 and 18.29 , from $\sigma$ (C24-C30) with occupancy 1.6625 to $\sigma^{*}$ (C31-C36) and $\sigma^{*}$ (C35-C38) taking the energies are 18.45 and 21.66, from $\sigma$ (C26-C32) has occupancy 1.6810 to $\sigma^{\star}$ (N11-C29) and $\sigma^{*}$ (C37-C39) having the energies are 23.52 and 17.08 , from $\sigma$ (C31-C36) with occupancy 1.6789 to $\sigma^{*}$ (C24-C30) and $\sigma^{\star}$ (C35-C38) having the energies are 20.82 and 19.77, from $\sigma$ (C33-C34) with occupancy 1.6309 to $\sigma^{*}$ (N9-C23) and $\sigma^{\star}$ (C22-C28) by taking the energies are 18.06 and 21.43 , from $\sigma$ (C35-C38) with the occupancy, is 1.6793 to $\sigma^{\star}$ (C24-C30) and $\sigma^{\star}$ (C31-C36) having the energies are 19.09 and 18.95 , and from $\sigma$ (C37-C39) has occupancy 1.6902 to $\sigma^{\star}$ (N11-C29) and $\sigma^{\star}$ (C26-C32) by with energy are 14.65 and $19.85 \mathrm{kcal} / \mathrm{mol}$.

The lone-pairs of electrons transfer from donor bonding orbitals to acceptor anti-bonding and antiRydberg orbital by with energy with suitable occupancies. From lone-pair electrons in bonding orbitals are $\mathrm{n}(\mathrm{F} 1), \mathrm{n}(\mathrm{F} 2), \mathrm{n}(\mathrm{O3}), \mathrm{n}(\mathrm{O} 4), \mathrm{n}(\mathrm{O} 4)$, and $\mathrm{n}(\mathrm{O})$ having the occupancies are 1.9276, 1.9264, 1.8338, $1.8332,1.9735$, and 1.9745 to anti-bonding and anti-Rydberg orbitals are $\sigma^{\star}$ (C24-C30), $\sigma^{\star}$ (C35-C38), $\sigma^{\star}$ (04-C25), $\sigma^{*}(\mathrm{~N} 6-\mathrm{C} 25), \mathrm{RY}^{*}(\mathrm{C} 25)$, and $\mathrm{RY}$ * (C27) by taking the energies are 17.45, 18.34, 14.89, 15.32, 15.87, and 16.93. From $n(05)$ has occupancy 1.8352 to $\sigma^{\star}$ (N7-C27) and $\sigma^{*}$ (N10-C27) having the energies are 28.02 and 27.14 , from $n$ (N6) having occupancy 1.7085 to $\sigma^{\star}(\mathrm{O} 4-\mathrm{C} 25)$ having the energy is $15.77 \mathrm{kcal} / \mathrm{mol}$, from $\mathrm{n}$ (N7) with the occupancy, is 1.6436 to $\sigma^{\star}$ (05-C27) and $\sigma^{\star}$ (C26-C32) having the energies are 58.01 and 41.66 , from $n(\mathrm{~N} 9)$ has occupancy 1.9177 to $\sigma^{\star}$ (C22-C23) and $\sigma^{\star}$ (C33-C34) having the energies are 11.22 and 9.61 , from $n$ (N10) with occupancy 1.6560 to $\sigma^{\star}$ (O5-C27) and $\sigma^{*}$ (N11C29) having the energies are 57.19 and 47.23 , and from $n$ (N11) has occupancy 1.9097 to $\sigma^{\star}$ (C26-C29) and $\sigma^{\star}$ (C37-C39) by with energy are 12.31 and $8.78 \mathrm{kcal} / \mathrm{mol}$.

The electrons transfer from anti-bonding orbitals to other anti-bonding orbitals by with the occupancies and with energy. From $\sigma^{\star}(\mathrm{O} 4-\mathrm{C} 25), \sigma^{\star}(\mathrm{O} 4-\mathrm{C} 25)$ and $\sigma^{\star}$ (C35-C38) having the occupancies are 0.1817, 0.2248 and 0.3857 to $\sigma^{\star}(\mathrm{O} 3-\mathrm{C} 25), \sigma^{\star}(\mathrm{O} 4-\mathrm{C} 25)$ and $\sigma^{\star}$ (C31-C36) by taking the energies are 21.19, 247.54 and 232.22 , from $\sigma^{\star}$ (N9-C23) has occupancy is 0.3877 to $\sigma^{*}$ (C22-C28) and $\sigma^{\star}$ (C33-C34) having the energies are 200.59 and 210.34 , from $\sigma^{\star}$ (N11-C29) with occupancy 0.4408 to $\sigma^{\star}$ (C26-C32) and $\sigma^{\star}$ (C37C39) having the energies are 268.80 and $137.72 \mathrm{kcal} / \mathrm{mol}$.

\subsection{Molecular electrostatic potentials (MESP) of Rimegepant}

Molecular electrostatic potentials explain the reaction sites appear in a molecule [39-41]. Fig.4 shows the reaction sites of rimegepant molecule, within \pm 18.98 Bohr $^{3}$ from the numerical value from -1.000 to 
0.100 , and from blue to red in color. The blue color on primary amine nitrogen and nitrogen in cycloheppyridinamine, carbonyl oxygens in piperidine-1-carboxylate, and $2 \mathrm{H}$-imidazopyridine-2-one groups, these are electrons-rich sites so electrophiles can easily attack these sites. The red color on all the carbon having protons in $2 \mathrm{H}$-imidazopyridine-2-one, piperidine-1-carboxylate, and carbon having protons and primary amine protons in cycloheptapyridinamine groups, these are electron-poor sites so nucleophiles can easily attack these sites.

\subsection{Average localized ionization energy (ALIE) property of Rimegepant}

Rimegepant molecule was optimized by using density functional theory DFT-B3LYP as a method, and 6$311 \mathrm{G}+(2 \mathrm{~d}, \mathrm{p})$ as a basis set. The average localized ionization energy can explain the resonance structure of the molecule, which also explains saturated and unsaturated bonds in the molecule, and its stability.

Fig. 5 shows the reaction sites of rimegepant molecule, within \pm 19.07 Bohr $^{3}$ from the numerical value from 0.000 to 2.000, and from blue to red in color [42-44]. The blush-green color indicates the unsaturated or moving or delocalized electrons in rimegepant molecule, in $2 \mathrm{H}$-imidazopyridine-2-one group, on amine nitrogen to carbon in cycloheptapyrinamine group, in ring and fluorines to carbons in 1,2-difluorophenyl group, these areas are unsaturated or delocalized electrons sites so addition reactions can occur in these sites. The blue color on all the protons in piperidine-1-carboxylate, cycloheptapyridinamide, and adjacent carbon in $2 \mathrm{H}$-imidazopyridin-2-one groups, these sites are saturated single bond sites so substitution reactions can occur in these sites.

\subsection{Non-covalent interactions ( $\mathrm{NCl})$ of Rimegepant}

Rimegepant molecule structure was optimized by using density functional theory DFT-B3LYP as a method, and 6-311G+(2d,p) as a basic set. The non-covalent interactions property explains the noncovalent but few types of bond attractions appear within the molecule, are hydrogen, van der Waals and steric type of forces [45-48]. Fig. 6 shows the non-covalent bond within rimegepant molecule, a graph plotted energy against a reduced density gradient. The hydrogen bond appears the energy from -0.198 to -0.006 a.u from fluorines to protons in the same 1,2-difluorophenyl and cycloheptapyridine groups. The van der Waals force of attractions from carbonyl oxygen in $2 \mathrm{H}$-imidazopyridin-2-one group to protons in piperidine-1-carboxylate group, and from oxygen in piperidine-1-carboxylate group to protons in the same group and protons in cycloheptapyridinamine group. The steric force of attractions shown from 1,2difluorophenyl group to cycloheptapyridinamine group, and from piperidine-1-carboxylate to $2 \mathrm{H}$ imidazopyridin-2-one group.

\subsection{Proton affinity and regioselectivity of protonation process of Rimegepant}

The Rimegepant molecule, with its six nitrogen atoms, shows very high proton affinity. But, as the nitrogen atoms do not reside in same environment, the proton affinities corresponding to the nitrogen atoms are indeed different. Looking at the structure of the molecule, it can be seen that there is one nitrogen atom (N8) in the form of a free amine group attached to the cycloheptane ring, while there are two nitrogen atoms (N9 \& N11) in the two pyridine rings. Again, one nitrogen atom (N6) can be observed 
as a constituent of the piperidine ring, while the imidazolone ring of the molecule contains two more nitrogen atoms (N7 \& N10). Fig-7 graphically represents and compares all these six proton affinities.

Fig-7 indicates that N8, i.e. the nitrogen atom of the free amine group has the greatest proton affinity, followed by N9, i.e. the nitrogen atom of the pyridine ring, which is fused with the cycloheptane ring. Then comes $\mathrm{N} 11$, i.e. the nitrogen atom of the other pyridine ring, which is fused with the imidazolone ring, followed by N6, i.e. the nitrogen atom of the piperidine ring. N7 and N10, that are present in the imidazolone ring, show comparatively less proton affinities. So, the order of the proton affinities of the six nitrogen atoms of the molecule becomes N8 $>$ N9 $>$ N11 $>$ N6 $>$ N7 $>$ N10.

$\mathrm{N} 8$ is the part of an isolated and independent amine group. It is the only nitrogen atom present in the Rimegepant molecule that is not a part of any ring. So, the availability of the lone pair of electrons on it is not reduced by any electron withdrawing effect. This makes N8 having the highest proton affinity among the nitrogen atoms of the molecule. Then come the nitrogen atoms of the pyridine rings $\mathrm{N} 9$ and $\mathrm{N} 11$ as the corresponding lone pairs of electrons do not participate in the resonance of the pyridine rings. The proton affinity of $\mathrm{N} 9$ is greater than that of $\mathrm{N} 11$, probably because, in case of the latter, the corresponding pyridine ring is fused with an imidazolone ring, which pulls the electron cloud of the pyridine ring and makes the lone pair of electrons of N11 comparative less donatable that N7. The proton affinity of N6 is further less because of the conjugation of $\mathrm{N} 6$ with the attached -COOR group, that reduces the availability of the lone pair of electrons on N6. The proton affinities of N7 and N10 are comparatively less than that of the rest of the nitrogen atoms, as these nitrogen atoms enjoy a cross conjugation with a carbonyl group. Protonation at any one of the nitrogen atoms between N7 and N11 is possible only at the cost of sacrificing this stabilizing cross conjugation. The proton affinity of N7 is slightly more than that of N10 probably as the former is attached to the piperidine ring that slightly increases the availability of the lone pair of electrons on it by $+\mathrm{l}$ effect.

\subsection{Molecular Docking for Rimegepant with SARS-CoV-2 proteins}

As the world is facing the severe pandemic COVID, we thought of assessing rimegepant's activity towards the known COVID proteins. We used molecular docking procedures for this study as mentioned in the methods section. This study gives biological activity information about the type of interactions between rimegepant and SARS-CoV-2 proteins (PDB IDs: 6LU7 [49] , 6M03 and 6W63 residues. Table S1 shows the docking results between rimegepant and SARS-CoV-2 proteins. The free enrgy of docking was founf to be $-9.2,-8.3$ and $-9.5 \mathrm{kcal} / \mathrm{mol}$ respectively for the $6 \mathrm{LU} 7,6 \mathrm{M} 03$ and $6 \mathrm{~W} 63$ systems. The free energy values are very high and hence we decided to investigate further.

The score values 5740, 5764 and 6002 are rimegepant with SARS-CoV-2 proteins are 6LU7, 6M03 and 6W63 respectively, surface area are $667.40,666.10$ and $711.80 \AA^{2}$ for rimegepant with SARS-CoV-2 proteins are 6LU7, 6M03 and 6W63 respectively, and minimum atomic contact energies are -280.28 , -265.46 and -327.41 for rimegepant with SARS-CoV-2 proteins are 6LU7, 6M03 and 6W63 respectively. Table S2 represents different interactions between rimegepant and the proteins (6LU7, 6M03 and 6W63) 
while Fig. 8 gives a pictorial representation of interactions between drug and aminoacid residues [40,5054]. Table $\mathbf{S} 3$ shows the non-bond interactions between Rimegepant with SARS-CoV-2 proteins (6LU7, $6 \mathrm{M} 03$, and $6 \mathrm{~W} 63)$.

\subsection{Molecular dynamic study for Rimegepant}

Root mean standard deviation (RMSD) fluctuations were used to assess if the protein-ligand had stabilized during the production stage. The results for the simulations of docked complexes are presented in Fig.8. For all the three protein-ligand complexes, equilibrium was attained at about 200ns showing protein RMSD fluctuations of less than $2 \AA$. Close examination of all the three proteins (6LU7, 6M03 and 6 W63) showed no distortion of either the protein or docked ligand. Further assessment with protein root mean square fluctuations (RMSF) also confirmed that all the proteins were stable in their states. Examining the RMSF (Fig S1 and Fig S2), the $N$ - and $C$-terminals fluctuated more than other residues as expected. The other amino acids showed average fluctuations of less than 2.4A for docked 6LU7 and $6 \mathrm{M} 03$ while $6 \mathrm{~W} 63$ had average fluctuations less than $2 \AA$. These findings demonstrate that all the three protein models were stable when docked with Rimegepant over an MD timescale of 400ns. Although there was a surge in Rimegepant (6W63) RMSD at around 325ns (Figure 8c), inspection of the trajectory revealed that the imidazolium side chain on the ligand was adjusting to a more stable position within the binding pocket.

Average protein-ligand interactions were computed from 250ns to the last frame, the region in which all the complexes had equilibrated. The results are outlined in Fig. 9 below.

On all models, hydrophobic interactions were found to be the primary forces for Rimegepant binding onto the receptors. Residues such as HIS, MET, CYS and LEU were among the major contributors to hydrophobic interactions as illustrated in Fig 10. In addition to hydrophobic interactions, water bridges, predominantly with glutamine, also play a major role towards the binding of Rimegepant to all the protein models. Lastly, pi-pi interactions, predominantly with histidine (HIS41), appeared to stabilize the docked complexes during the stipulated timeframe. Further investigation of binding strength on different proteins was performed using Molecular Mechanics Generalized Born Surface Area (MM/GBSA) calculations to predict the estimate binding free energies of Rimegepant on the selected protein models. The MMGBSA module estimate binding free energy $\left(\Delta \mathrm{G}_{\text {bind }}\right)$ as a difference between the docked complex $\left(\Delta \mathrm{G}_{\text {complex }}\right)$ and the free receptor $\left(\Delta G_{\text {receptor }}\right)$ and ligand $\left(\Delta G_{\text {ligand }}\right)$ as shown below.

$\Delta \mathrm{G}_{\text {bind }}=\Delta \mathrm{G}_{\text {complex }}-\Delta \mathrm{G}_{\text {receptor }}-\Delta \mathrm{G}_{\text {ligand }}$

There are several parameters that contribute towards $\Delta \mathrm{G}_{\text {bind }}$, however, here we only present those that had the largest contributions, for example $\Delta \mathrm{G}_{\text {bind_Vdw }}$ and $\Delta \mathrm{G}_{\text {bind_Coulomb, }}$ among others, (Table 2.) In this work, MM/GBSA energies were calculated from frame 2500 to frame 4000 where the system had equilibrated. The results are as presented in Table 2.

Table.2 MMGBSA* results of Rimegepant on the selected PDB models 


\begin{tabular}{|lllllll|}
\hline PDB ID & $\Delta \mathrm{G}_{\text {bind }}$ & $\Delta \mathrm{G}_{\text {bind_Coulomb }}$ & $\Delta \mathrm{G}_{\text {bind_Covalent }}$ & $\Delta \mathrm{G}_{\text {bind_Hbond }}$ & $\Delta \mathrm{G}_{\text {bind_Solv }}$ & $\Delta \mathrm{G}_{\text {bind_VdW }}$ \\
\hline 6LU7 & -67.13 & -31.99 & 1.51 & -1.65 & 30.54 & -46.89 \\
\hline 6M03 & -65.30 & -46.86 & 3.22 & -0.84 & 51.28 & -54.58 \\
\hline 6W63 & -52.02 & -29.49 & 3.89 & -0.11 & 39.51 & -47.03 \\
\hline
\end{tabular}

*All values are reported in $\mathrm{kcal} / \mathrm{mol}$

Although favorable binding is shown on all models, binding of Rimegepant to PDB model 6LU7 appeared to be the most favored. In all models, Van der Waals forces were the major contributors toward the binding energy. This is somewhat in agreement with our docking results where Rimegepant and 6LU7 have higher full fitness, inter full fitness, solvent full fitness and better $\Delta G$ complex solvent polar than other two proteins.

\section{Conclusions}

The results from frontier molecular analysis chemical descriptors of rimegepant were analyzed. NBO studies revealed the intensity of various intramolecular interactions. TD-DFT study of rimegepant explained the UV-visible spectral property, and major and minor contributions orbitals. The various wavefunction studies are MESP, ALIE, and $\mathrm{NCl}$ data helped to predict the more than one reactivity and active site are 1,2 difluorophenyl, cycloheptapyridinamine, piperidine-1-carboxylate, and $2 \mathrm{H}$ imidazopyridin-2-one in rimegepant. Docking studies explained the $\Delta \mathrm{G}$, scores, minimum atomic contact energies, and different types of interactions between rimegepant and SARS-CoV-2 proteins. Time dependent behaviours of docked complexes were investigated using molecular dynamics simulations over a time frame of $400 \mathrm{~ns}$. Herein, intermolecular forces such as water bridges, $\pi-\pi$ and hydrophobic interactions were found to be the major contributors for ligand binding to receptor pocket. Estimate binding free energies using MMGBSA further demonstrated that rimegepant binding to the selected protein models (6LU7, 6M03 and 6W63) is favourable on all models with PDB 6LU7 being the most favoured. It can be concluded that this compound may be investigated further for a potential medicine to act against the SARS-CoV-2.

\section{Declarations}

\section{Funding}

The authors would like to acknowledge the Faculty of Science: University of Johannesburg: Centre for Nanomaterials Science Research, Department of Chemical Sciences and the National Research Foundation (TTK170405225933) South Africa. The authors are also thankful to the Centre for High Performance Computing (CHPC) for computational resources.

\section{Declaration of interests}


The authors declare that they have no known competing financial interests or personal relationships that could have appeared to influence the work reported in this paper.

\section{Availability of data and material}

Additional materials are available in the Supplementary Information Files.

\section{Code availability}

We have not developed any new codes. Existing codes have been used and they are properly cited.

\section{Authors' contributions}

Pooventhiran: DFT studies, manuscript writing

Ephraim Felix Marondedze: Molecular dynamics study

Penny Poomani Govender: MD study supervision and writing, funding for MD studies

Utsab Bhattacharyya: Proton affinity studies, manuscript draft correction

Jagadeeswara Rao: Docking studies

Elham S. Aazam: Method development and standardization

Jinesh M. Kuthanapillil: Manuscript preparation, data analysis

Tomlal Jose E: Manuscript preparation, data curation and validation

Renjith Thomas: Conceiving of the problem, supervision, software, method development, manuscript draft

\section{References}

1. Russo AF, CGRP-Based Migraine Therapeutics: How Might They Work, Why So Safe, and Next? W, ACS Pharmacol. Transl. Sci. 2 (2019) 2-8. https://doi.org/10.1021/acsptsci.8b00036

2. Croop R, Goadsby PJ, Stock DA, Conway CM, Forshaw M, Stock EG, Coric V, Lipton RB (2019) Efficacy, safety, and tolerability of rimegepant orally disintegrating tablet for the acute treatment of migraine: a randomised, phase 3, double-blind, placebo-controlled trial. Lancet 394:737-745. https://doi.org/10.1016/S0140-6736(19)31606-X

3. Sparrow AM, Searles JW (2019) The market for migraine drugs. Nat Rev Drug Discov 18:333-334. https://doi.org/10.1038/d41573-018-00014-3

4. Gingell JJ, Rees TA, Hendrikse ER, Siow A, Rennison D, Scotter J, Harris PWR, Brimble MA, Walker CS, Hay DL (2020) Distinct Patterns of Internalization of Different Calcitonin Gene-Related Peptide 
Receptors, ACS Pharmacol. TransI Sci 3:296-304. https://doi.org/10.1021/acsptsci.9b00089

5. Hendrikse ER, Liew LP, Bower RL, Bonnet M, Jamaluddin MA, Prodan N, Richards KD, Walker CS, Pairaudeau G, Smith DM, Rujan R-M, Sudra R, Reynolds CA, Booe JM, Pioszak AA, Flanagan JU, Hay MP, Hay DL (2020) Identification of Small-Molecule Positive Modulators of Calcitonin-like ReceptorBased Receptors, ACS Pharmacol. Transl Sci 3:305-320. https://doi.org/10.1021/acsptsci.9b00108

6. Olesen J, Ashina M (2019) Calcitonin gene-related peptide - beyond migraine prophylaxis. Nat Rev Neurol 15:562-564. https://doi.org/10.1038/s41582-019-0258-1

7. Luo G, Chen L, Conway CM, Kostich W, Macor JE, Dubowchik GM (2015) Asymmetric Synthesis of Heterocyclic Analogues of a CGRP Receptor Antagonist for Treating Migraine. Org Lett 17:59825985. https://doi.org/10.1021/acs.orglett.5b02921

8. Scott LJ (2020) Rimegepant: First Approval. Drugs 80:741-746. https://doi.org/10.1007/s40265020-01301-3

9. Zhou P, Yang X-L, Wang X-G, Hu B, Zhang L, Zhang W, Si H-R, Zhu Y, Li B, Huang C-L, Chen H-D, Chen J, Luo Y, Guo H, Jiang R-D, Liu M-Q, Chen Y, Shen X-R, Wang X, Zheng X-S, Zhao K, Chen Q-J, Deng F, Liu L-L, Yan B, Zhan F-X, Wang Y-Y, Xiao G-F, Shi Z-L (2020) A pneumonia outbreak associated with a new coronavirus of probable bat origin. Nature 579:270-273. https://doi.org/10.1038/s41586-0202012-7

10. Lake MA (2020) What we know so far: COVID-19 current clinical knowledge and research. Clin Med 20:124-127. https://doi.org/10.7861/clinmed.2019-coron

11. Kaur SP, Gupta V (2020) COVID-19 Vaccine: A comprehensive status report. Virus Res 288:198114. https://doi.org/10.1016/j.virusres.2020.198114

12. Ong E, Wong MU, Huffman A, He Y (2020) COVID-19 coronavirus vaccine design using reverse vaccinology and machine learning. BioRxiv Prepr Serv Biol.

https://doi.org/10.1101/2020.03.20.000141

13. Forni G, Mantovani A, Forni G, Mantovani A, Moretta L, Rappuoli R, Rezza G, Bagnasco A, Barsacchi G, Bussolati G, Cacciari M, Cappuccinelli P, Cheli E, Guarini R, Bacci ML, Mancini M, Marcuzzo C, Morrone MC, Parisi G, Pasquino G, Patrono C, Curzio AQ, Remuzzi G, Roncaglia A, Schiaffino S, Vineis $P$ (2021) R. on behalf of the COVID-19 Commission of Accademia Nazionale dei Lincei, COVID-19 vaccines: where we stand and challenges ahead. Cell Death Differ 28:626-639. https://doi.org/10.1038/s41418-020-00720-9

14. Colson P, Rolain JM, Raoult D (2020) Chloroquine for the 2019 novel coronavirus SARS-CoV-2. Int J Antimicrob Agents 55:105923. https://doi.org/10.1016/j.ijantimicag.2020.105923

15. Vincent MJ, Bergeron E, Benjannet S, Erickson BR, Rollin PE, Ksiazek TG, Seidah NG, Nichol ST, Chloroquine is a potent inhibitor of SARS coronavirus infection and spread, Virol J 2 (2005). https://doi.org/10.1186/1743-422X-2-69

16. Touret F, de Lamballerie X (2020) Of chloroquine and COVID-19. Antiviral Res 177:104762. https://doi.org/10.1016/j.antiviral.2020.104762 
17. Savarino A, Di Trani L, Donatelli I, Cauda R, Cassone A (2006) New insights into the antiviral effects of chloroquine. Lancet Infect Dis 6:67-69. https://doi.org/10.1016/S1473-3099(06)70361-9

18. Wu R, Wang L, Kuo H-CD, Shannar A, Peter R, Chou PJ, Li S, Hudlikar R, Liu X, Liu Z, Poiani GJ, Amorosa L, Brunetti L, Kong A-N (2020) An Update on Current Therapeutic Drugs Treating COVID-19, Curr. Pharmacol Reports 6:56-70. https://doi.org/10.1007/s40495-020-00216-7

19. Ko W-C, Rolain J-M, Lee N-Y, Chen P-L, Huang C-T, Lee P-I, Hsueh P-R, Arguments in favor of remdesivir for treating SARS-CoV-2 infections., Int J Antimicrob Agents (2020) 105933. https://doi.org/10.1016/j.ijantimicag.2020.105933

20. Lai CC, Shih TP, Ko WC, Tang HJ, Hsueh PR, Severe acute respiratory syndrome coronavirus 2 (SARSCoV-2) and coronavirus disease-2019 (COVID-19): The epidemic and the challenges, Int J Antimicrob Agents 55 (2020). https://doi.org/10.1016/j.ijantimicag.2020.105924

21. Al-Zaqri N, Pooventhiran T, Alsalme A, Warad I, John AM, Thomas R (2020) Structural and physicochemical evaluation of melatonin and its solution-state excited properties, with emphasis on its binding with novel coronavirus proteins. J Mol Liq 318:114082.

https://doi.org/https://doi.org/10.1016/j.molliq.2020.114082

22. Al-Zaqri N, Pooventhiran T, Alharthi FA, Bhattacharyya U, Thomas $R$, Structural investigations, quantum mechanical studies on proton and metal affinity and biological activity predictions of selpercatinib, J Mol Liq (2020) 114765.

https://doi.org/https://doi.org/10.1016/j.molliq.2020.114765

23. Alsalme A, Pooventhiran T, Al-Zaqri N, Rao DJ, Rao SS, Thomas R (2020) Modelling the structural and reactivity landscapes of tucatinib with special reference to its wavefunction-dependent properties and screening for potential antiviral activity. J Mol Model 26:341. https://doi.org/10.1007/s00894-020-04603-1

24. Jiang Y, Liu L, Manning M, Bonahoom M, Lotvola A, Yang Z, Yang Z-Q, Structural analysis, virtual screening and molecular simulation to identify potential inhibitors targeting 2'-0-ribose methyltransferase of SARS-CoV-2 coronavirus., J Biomol Struct Dyn (2020) 1-16. https://doi.org/10.1080/07391102.2020.1828172

25. Frisch MJ, Trucks GW, Schlegel HB, Scuseria GE, Robb MA, Cheeseman JR, Scalmani G, Barone V, Mennucci B, Petersson GA, Nakatsuji H, Caricato M, Li X, Hratchian HP, Izmaylov AF, Bloino J, Zheng G, Sonnenberg JL, Hada M, Ehara M, Toyota K, Fukuda R, Hasegawa J, Ishida M, Nakajima T, Honda Y, Kitao O, Nakai H, Vreven T, Montgomery JA Jr, Peralta JE, Ogliaro F, Bearpark M, Heyd JJ, Brothers E, Kudin KN, Staroverov VN, Kobayashi R, Normand J, Raghavachari K, Rendell A, Burant JC, lyengar SS, Tomasi J, Cossi M, Rega N, Millam JM, Klene M, Knox JE, Cross JB, Bakken V, Adamo C, Jaramillo J, Gomperts R, Stratmann RE, Yazyev O, Austin AJ, Cammi R, Pomelli C, Ochterski JW, Martin RL, Morokuma K, Zakrzewski VG, Voth GA, Salvador P, Dannenberg JJ, Dapprich S, Daniels AD, Farkas O, J.B. Foresman, J. V Ortiz, J. Cioslowski, D.J. Fox, Gaussian09 Revision D.01, (2013)

26. Orio M, Pantazis DA, Neese F (2009) Density functional theory. Photosynth Res 102:443-453. https://doi.org/10.1007/s11120-009-9404-8 
27. Yanai T, Tew DP, Handy NC (2004) A new hybrid exchange-correlation functional using the Coulombattenuating method (CAM-B3LYP). Chem Phys Lett 393:51-57.

https://doi.org/10.1016/J.CPLETT.2004.06.011

28. O'boyle NM, Tenderholt AL, Langner KM (2008) CCLIB: A library for package-independent computational chemistry algorithms. J Comput Chem 29:839-845. https://doi.org/10.1002/jcc.20823

29. Lu T, Chen F (2012) Multiwfn: A multifunctional wavefunction analyzer. J Comput Chem 33:580592. https://doi.org/10.1002/jcc.22885

30. Parr RG, Pearson RG (1983) Absolute hardness: companion parameter to absolute electronegativity. J Am Chem Soc 105:7512-7516. https://doi.org/10.1021/ja00364a005

31. Johnson ER, Keinan S, Mori-Sánchez P, Contreras-García J, Cohen AJ, Yang W (2010) Revealing noncovalent interactions. J Am Chem Soc 132:6498-6506. https://doi.org/10.1021/ja100936w

32. Burley SK, Berman HM, Bhikadiya C, Bi C, Chen L, Di Costanzo L, Christie C, Dalenberg K, Duarte JM, Dutta S, Feng Z, Ghosh S, Goodsell DS, Green RK, Guranović V, Guzenko D, Hudson BP, Kalro T, Liang Y, Lowe R, Namkoong H, Peisach E, Periskova I, Prlić A, Randle C, Rose A, Rose P, Sala R, Sekharan M, Shao C, Tan L, Tao Y-P, Valasatava Y, Voigt M, Westbrook J, Woo J, Yang H, Young J, Zhuravleva M, Zardecki C (2018) RCSB Protein Data Bank: biological macromolecular structures enabling research and education in fundamental biology, biomedicine, biotechnology and energy. Nucleic Acids Res 47:D464-D474. https://doi.org/10.1093/nar/gky1004

33. Stewart JJP (1989) Optimization of parameters for semiempirical methods I. Method. J Comput Chem 10:209-220. https://doi.org/10.1002/jcc.540100208

34. Jin Z, Du X, Xu Y, Deng Y, Liu M, Zhao Y, Zhang B, Li X, Zhang L, Peng C, Duan Y, Yu J, Wang L, Yang K, Liu F, Jiang R, Yang X, You T, Liu X, Yang X, Bai F, Liu H, Liu X, Guddat LW, Xu W, Xiao G, Qin C, Shi Z, Jiang H, Rao Z, Yang H (2020) Structure of Mpro from SARS-CoV-2 and discovery of its inhibitors. Nature 582:289-293. https://doi.org/10.1038/s41586-020-2223-y

35. Mesecar AD, RCSB PDB - 6W63: Structure of COVID-19 main protease bound to potent broadspectrum non-covalent inhibitor X77, RCSB. (2020). https://doi.org/10.2210/pdb6W63/pdb

36. Trott O, Olson AJ (2010) AutoDock Vina: improving the speed and accuracy of docking with a new scoring function, efficient optimization, and multithreading. J Comput Chem 31:455-461. https://doi.org/10.1002/jcc. 21334

37. Trott O, Olson AJ, AutoDock Vina: Improving the speed and accuracy of docking with a new scoring function, efficient optimization, and multithreading, J Comput Chem (2009) NA-NA. https://doi.org/10.1002/jcc. 21334

38. Discovery Studio BIOVA, Discov. Stud. Client V17, San Diego, Dassault Syst. (2017)

39. Schrödinger Release 2019-3: Desmond Molecular Dynamics System, (2019)

40. Kevin J, Bowers E, Chow H, Xu RO, Dror MP, Eastwood BA, Gregersen JL, Klepeis I, Kolossvary MA, Moraes FD, Sacerdoti JK, Salmon Y, Shan DE, Shaw, Scalable Algorithms for Molecular Dynamics Simulations on Commodity Clusters, in: Barbara Horner-Miller (Ed.), Proc. ACM/IEEE Conf. 
Supercomput. (SC06), Tampa, Florida, 2006, Novemb. 11-17, [publisher not identified], Tampa, Florida, 2006

41. Schrödinger Release 2020-3: Maestro, (2020)

42. Harder E, Damm W, Maple J, Wu C, Reboul M, Xiang JY, Wang L, Lupyan D, Dahlgren MK, Knight JL, Kaus JW, Cerutti DS, Krilov G, Jorgensen WL, Abel R, Friesner RA (2016) OPLS3: A Force Field Providing Broad Coverage of Drug-like Small Molecules and Proteins. J Chem Theory Comput 12:281-296. https://doi.org/10.1021/acs.jctc.5b00864

43. Martyna GJ, Tobias DJ, Klein ML (1994) Constant pressure molecular dynamics algorithms. J Chem Phys 101:4177-4189. https://doi.org/10.1063/1.467468

44. Mary YS, Miniyar PB, Mary YS, Resmi KS, Panicker CY, Armaković S, Armaković SJ, Thomas R, Sureshkumar B (2018) Synthesis and spectroscopic study of three new oxadiazole derivatives with detailed computational evaluation of their reactivity and pharmaceutical potential. J Mol Struct 1173:469-480. https://doi.org/10.1016/j.molstruc.2018.07.026

45. Hossain M, Thomas R, Mary YS, .Resmi KS, Armaković S, Armaković SJ, Nanda AK, Vijayakumar G, Van Alsenoy C (2018) Understanding reactivity of two newly synthetized imidazole derivatives by spectroscopic characterization and computational study. J Mol Struct 1158:176-196. https://doi.org/10.1016/j.molstruc.2018.01.029

46. Thomas R, Hossain M, Mary YS, Resmi KS, Armaković S, Armaković SJ, Nanda AK, Ranjan VK, Vijayakumar G, Van Alsenoy C (2018) Spectroscopic analysis and molecular docking of imidazole derivatives and investigation of its reactive properties by DFT and molecular dynamics simulations. J Mol Struct 1158:156-175. https://doi.org/10.1016/J.MOLSTRUC.2018.01.021

47. Hosna S, Janzen DE, Mary YS, Resmi KS, Thomas R, Mohamed R, Wajda S (2018) Molecular structure, spectroscopic, dielectric and thermal study, nonlinear optical properties, natural bond orbital, HOMO-LUMO and molecular docking analysis of (C6Cl2O4) (C10H14N2F)2.2H2O, Spectrochim. Acta Part A Mol. Biomol Spectrosc 204:328-339.

https://doi.org/10.1016/J.SAA.2018.06.062

48. Domingo L, Ríos-Gutiérrez M, Pérez P (2016) Applications of the Conceptual Density Functional Theory Indices to Organic Chemistry Reactivity. Molecules 21:748. https://doi.org/10.3390/molecules21060748

49. De Proft F, Sablon N, Tozer DJ, Geerlings P (2007) Calculation of negative electron affinity and aqueous anion hardness using Kohn-Sham HOMO and LUMO energies. In: Faraday Discuss. Royal Society of Chemistry, pp 151-159. https://doi.org/10.1039/b605302p

50. Chattaraj PK, Sarkar U, Roy DR, Index E (2006) Chem Rev 106:2065-2091. https://doi.org/10.1021/cr040109f

51. Chattaraj PK, Giri S (2009) Electrophilicity index within a conceptual DFT framework. Annu Rep Prog Chem \{ Sect C Phys Chem 105:13-39. https://doi.org/10.1039/B802832J

52. Parthasarathi R, Subramanian V, Roy DR, Chattaraj PK (2004) Electrophilicity index as a possible descriptor of biological activity. Bioorg Med Chem 12:5533-5543. 
https://doi.org/https://doi.org/10.1016/j.bmc.2004.08.013

53. Parr RG, Szentpály Lv, Liu S, Index E (1999) J Am Chem Soc 121:1922-1924. https://doi.org/10.1021/ja983494x

54. Domingo LR, Ríos-Gutiérrez M, Pérez P (2016) Applications of the Conceptual Density Functional Theory Indices to Organic Chemistry Reactivity. Molecules 21:748. https://doi.org/10.3390/molecules21060748

55. P. Politzer, F. Abu-Awwad, J.S. Murray, Comparison of density functional and Hartree-Fock average local ionization energies on molecular surfaces, Int. J. Quantum Chem. 69 (1998) 607-613. https://doi.org/10.1002/(SICI)1097-461X(1998)69:4<607::AID-QUA18>3.0.CO;2-W.

56. Politzer P, Laurence PR, Jayasuriya K (1985) Molecular electrostatic potentials: an effective tool for the elucidation of biochemical phenomena. Environ Health Perspect 61:191-202. https://doi.org/10.1289/ehp.8561191

57. Murray JS, Seminario JM, Politzer P, Sjoberg P (1990) Average local ionization energies computed on the surfaces of some strained molecules. Int J Quantum Chem 38:645-653. https://doi.org/10.1002/qua.560382462

58. Politzer P, Murray JS (2002) The fundamental nature and role of the electrostatic potential in atoms and molecules. Theor Chem Acc 108:134-142. https://doi.org/10.1007/s00214-002-0363-9

59. Politzer P, Murray JS (2018) An Occam's razor approach to chemical hardness: lex parsimoniae. J Mol Model 24:332. https://doi.org/10.1007/s00894-018-3864-8

60. Politzer P, Murray JS, Bulat FA (2010) Average local ionization energy: A review. J Mol Model 16:1731-1742. https://doi.org/10.1007/s00894-010-0709-5

61. Politzer P, Lane P, Concha MC (2002) Atomic and molecular energies in terms of electrostatic potentials at nuclei. Int J Quantum Chem 90:459-463. https://doi.org/10.1002/qua.10105

62. Barone V, Cossi M, Tomasi J (1997) A new definition of cavities for the computation of solvation free energies by the polarizable continuum model. J Chem Phys 107:3210-3221. https://doi.org/10.1063/1.474671

63. Cossi M, Barone V, Cammi R, Tomasi J (1996) Ab initio study of solvated molecules: a new implementation of the polarizable continuum model. Chem Phys Lett 255:327-335. https://doi.org/https://doi.org/10.1016/0009-2614(96)00349-1

64. Klamt A, Moya C, Palomar J (2015) A Comprehensive Comparison of the IEFPCM and SS(V)PE Continuum Solvation Methods with the COSMO Approach. J Chem Theory Comput 11:4220-4225. https://doi.org/10.1021/acs.jctc.5b00601

65. Glendening FWED, Reed AE, Carpenter JE, NBO 3.1, (2003)

66. Jeeva S, Muthu S, Thomas R, Raajaraman BR, Mani G, Vinitha G (2020) Co-crystals of urea and hexanedioic acid with third-order nonlinear properties: An experimental and theoretical enquiry. $\mathrm{J} \mathrm{Mol}$ Struct 1202:127237. https://doi.org/10.1016/j.molstruc.2019.127237 
67. Sheena Mary Y, Shyma Mary Y, Thomas R, Resmi KS, Narayana B, Samshuddin S, Sarojini BK, Spectroscopic and Theoretical Studies of Potential Anti-Inflammatory Polycyclic Aromatic Fluorophenyl Substituted Acyclic and Heterocyclic Analogues Synthesized from 4,4'Difluorophenylchalcone, Polycycl. Aromat. Compd. In Press (2019) 1-13. https://doi.org/10.1080/10406638.2019.1699836

68. Al-Otaibi JS, Mary YS, Armaković S, Thomas R (2020) Hybrid and bioactive cocrystals of pyrazinamide with hydroxybenzoic acids: Detailed study of structure, spectroscopic characteristics, other potential applications and noncovalent interactions using SAPT. J Mol Struct 1202:127316. https://doi.org/10.1016/j.molstruc.2019.127316

69. Beegum S, Mary YS, Mary YS, Thomas R, Armaković S, Armaković SJ, Zitko J, Dolezal M, Van Alsenoy $C$ (2020) Exploring the detailed spectroscopic characteristics, chemical and biological activity of two cyanopyrazine-2-carboxamide derivatives using experimental and theoretical tools. Spectrochim Acta - Part A Mol Biomol Spectrosc 224:1-13. https://doi.org/10.1016/j.saa.2019.117414

70. Thomas R, Varghese E, Thomas ME, George J, Vijayakumar G (2015) Time Dependent Density Functional Study on the Electronic Spectra of Some Derivatives of Triafulvalene. Can Chem Trans 3:438-435

71. Thomas R, Mary YS, Resmi KS, Narayana B, Sarojini SBK, Armaković S, Armaković SJ, Vijayakumar G, Van Alsenoy C, Mohan BJ (2019) Synthesis and spectroscopic study of two new pyrazole derivatives with detailed computational evaluation of their reactivity and pharmaceutical potential. $J$ Mol Struct 1181:599-612. https://doi.org/10.1016/j.molstruc.2019.01.014

72. Matondo A, Thomas R, Tsalu PV, Mukeba CT (2019) V. Mudogo, a-methylation and a-fluorination electronic effects on the regioselectivity of carbonyl groups of uracil by $\mathrm{H}$ and triel bonds in the interaction of $\mathrm{U}, \mathrm{T}$ and 5FU with $\mathrm{HCl}$ and $\mathrm{TrH} 3(\mathrm{Tr}=\mathrm{B}, \mathrm{Al})$. J Mol Graph Model 88:237-246

73. Sheena Mary Y, Ertan-Bolelli T, Thomas R, Krishnan AR, Bolelli K, Kasap EN, Onkol T, Yildiz I, Quantum Mechanical Studies of Three Aromatic Halogen-Substituted Bioactive Sulfonamidobenzoxazole Compounds with Potential Light Harvesting Properties, Polycycl. Aromat. Compd. In Press (2019) https://doi.org/10.1080/10406638.2019.1689405

74. Thomas R, Mary YS, Resmi KS, Narayana B, Sarojini BK, Vijayakumar G, Van Alsenoy C (2019) Two neoteric pyrazole compounds as potential anti-cancer agents: Synthesis, electronic structure, physico-chemical properties and docking analysis. J Mol Struct 1181:455-466

75. Mary YS, Mary YS, Thomas R, Narayana B, Samshuddin S, Sarojini BK, Armaković S, Armaković SJ, Pillai GG, Theoretical Studies on the Structure and Various Physico-Chemical and Biological Properties of a Terphenyl Derivative with Immense Anti-Protozoan Activity, Polycycl. Aromat. Compd. In Press (2019) https://doi.org/10.1080/10406638.2019.1624974

76. Rao DJ, Mary YS, Mary YS, Resmi KS, Thomas R, Structure, Spectral Features, Bioactivity and Light Harvesting Properties of Methyl and Dimethyl Anthracene: Experimental and First Principle Studies, Polycycl. Aromat. Compd. (2019) 1-15 
77. Al-Otaibi JS, Sheena Mary Y, Shyma Mary Y, Panicker CY, Thomas R (2019) Cocrystals of pyrazinamide with p-toluenesulfonic and ferulic acids: DFT investigations and molecular docking studies. J Mol Struct 1175:916-926. https://doi.org/10.1016/j.molstruc.2018.08.055

78. Afzal A, Thayyil MS, Shariq M, Mary YS, Resmi KS, Thomas R, Islam N, Abinu AJ, Anti-Cancerous Brucine and Colchicine: Experimental and Theoretical Characterization, ChemistrySelect. 4 (2019) 11441-11454. https://doi.org/10.1002/slct.201902698

79. Al-Otaibi JS, Mary YS, Mary YS, Thomas R (2019) Quantum mechanical and photovoltaic studies on the cocrystals of hydrochlorothiazide with isonazid and malonamide. J Mol Struct 1197:719-726. https://doi.org/https://doi.org/10.1016/j.molstruc.2019.07.110

80. Al-Otaibi JS, Mary YS, Thomas R, Narayana B, Theoretical Studies into the Spectral Characteristics, Biological Activity, and Photovoltaic Cell Efficiency of Four New Polycyclic Aromatic Chalcones, Polycycl Aromat Compd (2020) 1-15. https://doi.org/10.1080/10406638.2020.1747097

\section{Figures}

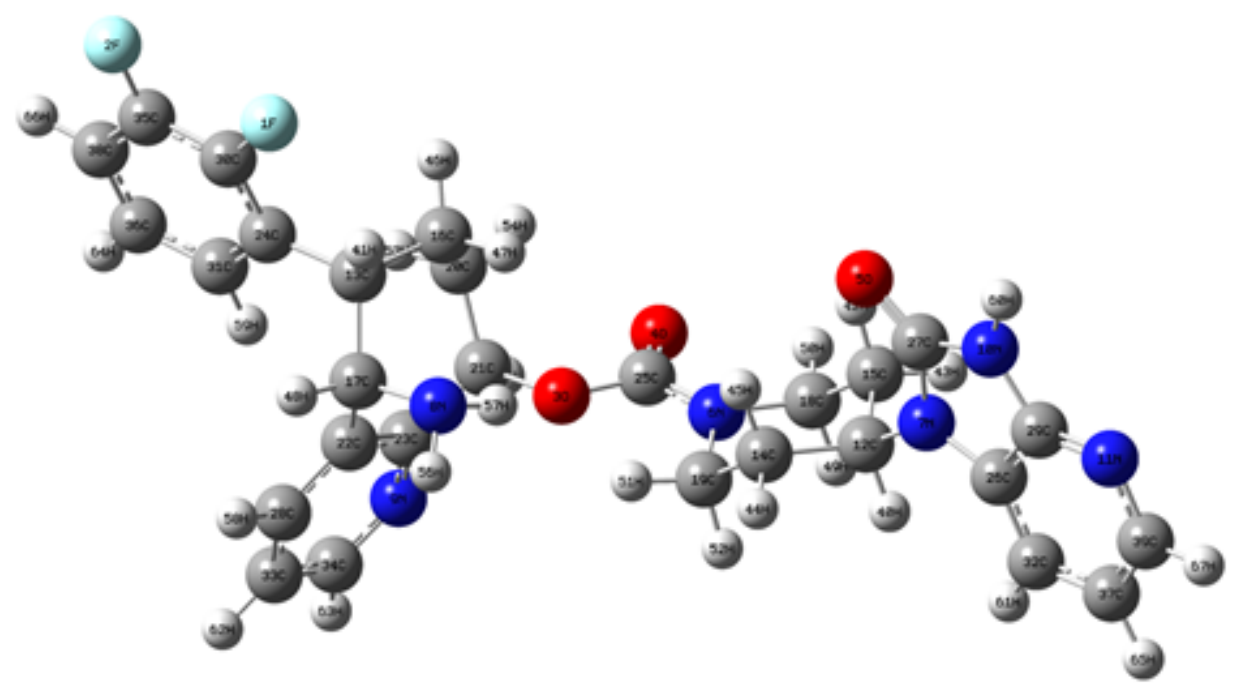

\section{Figure 1}

Optimised structure of Rimegepant at B3LYP/6-311G+(2d,p). (Blue colour indicated nitrogen atoms, redoxygen, black-carbon, grey-hydrogen and light blue- fluorine) 


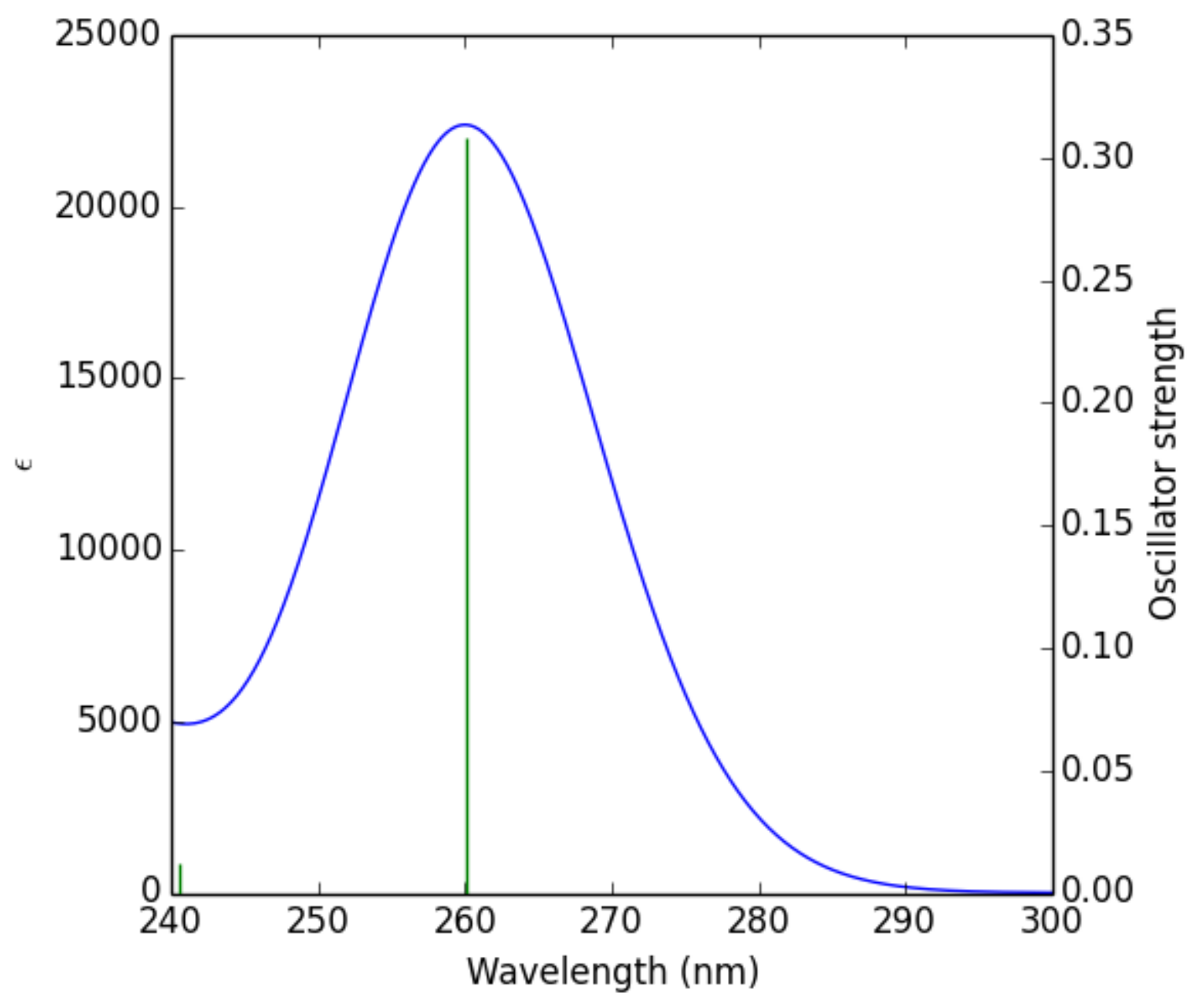

Figure 2

TD-DFT simulated UV-visible spectrum of Rimegepant 

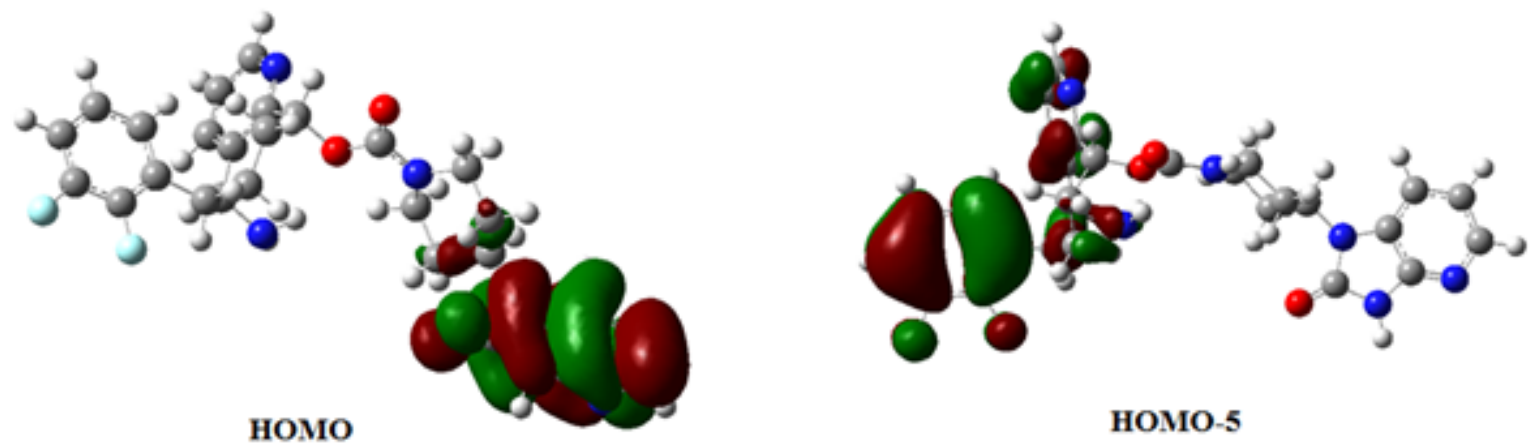

HOMO-5

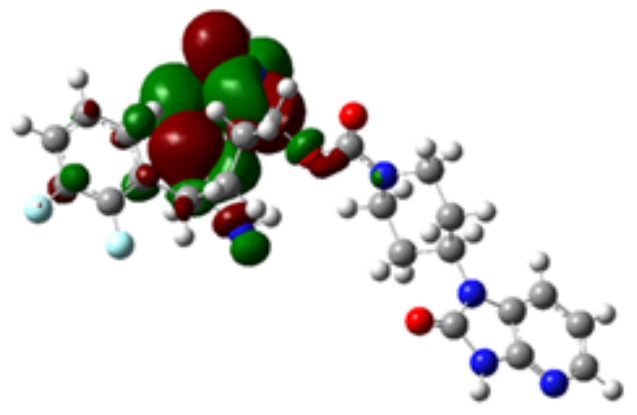

LUMO+1

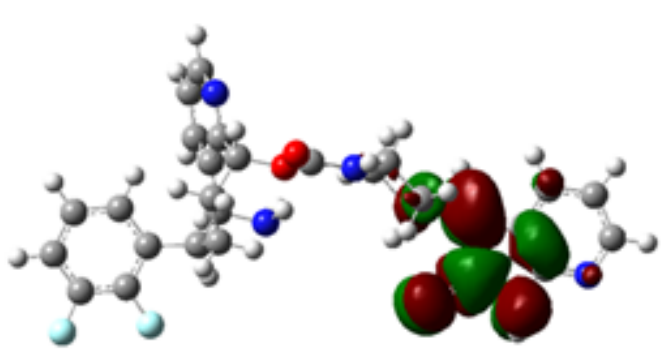

LUMO+8

Figure 3

Representative FMO's of Rimegepant

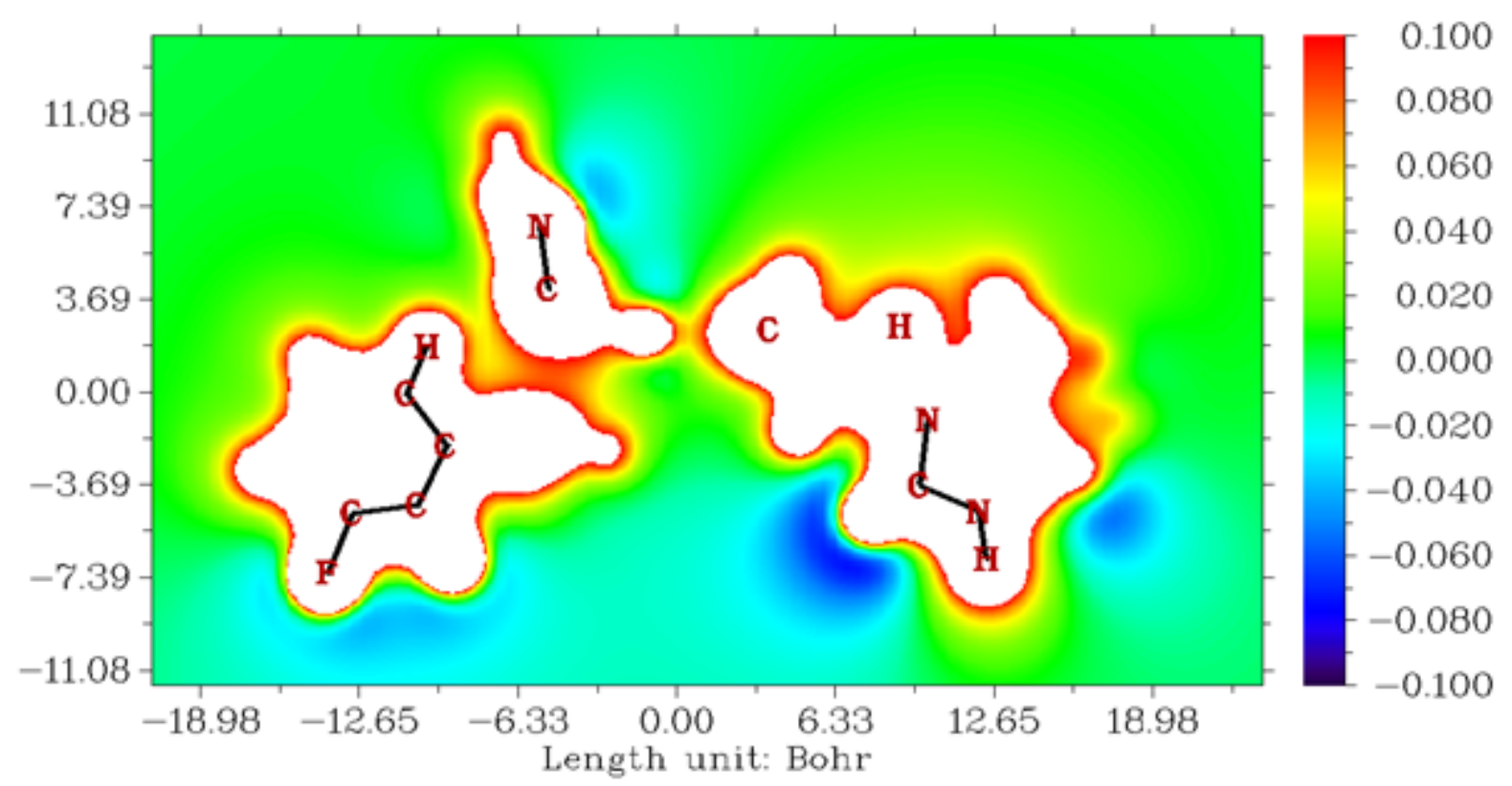


Figure 4

Molecular electrostatic potential map of Rimegepant depicting reactivity centres

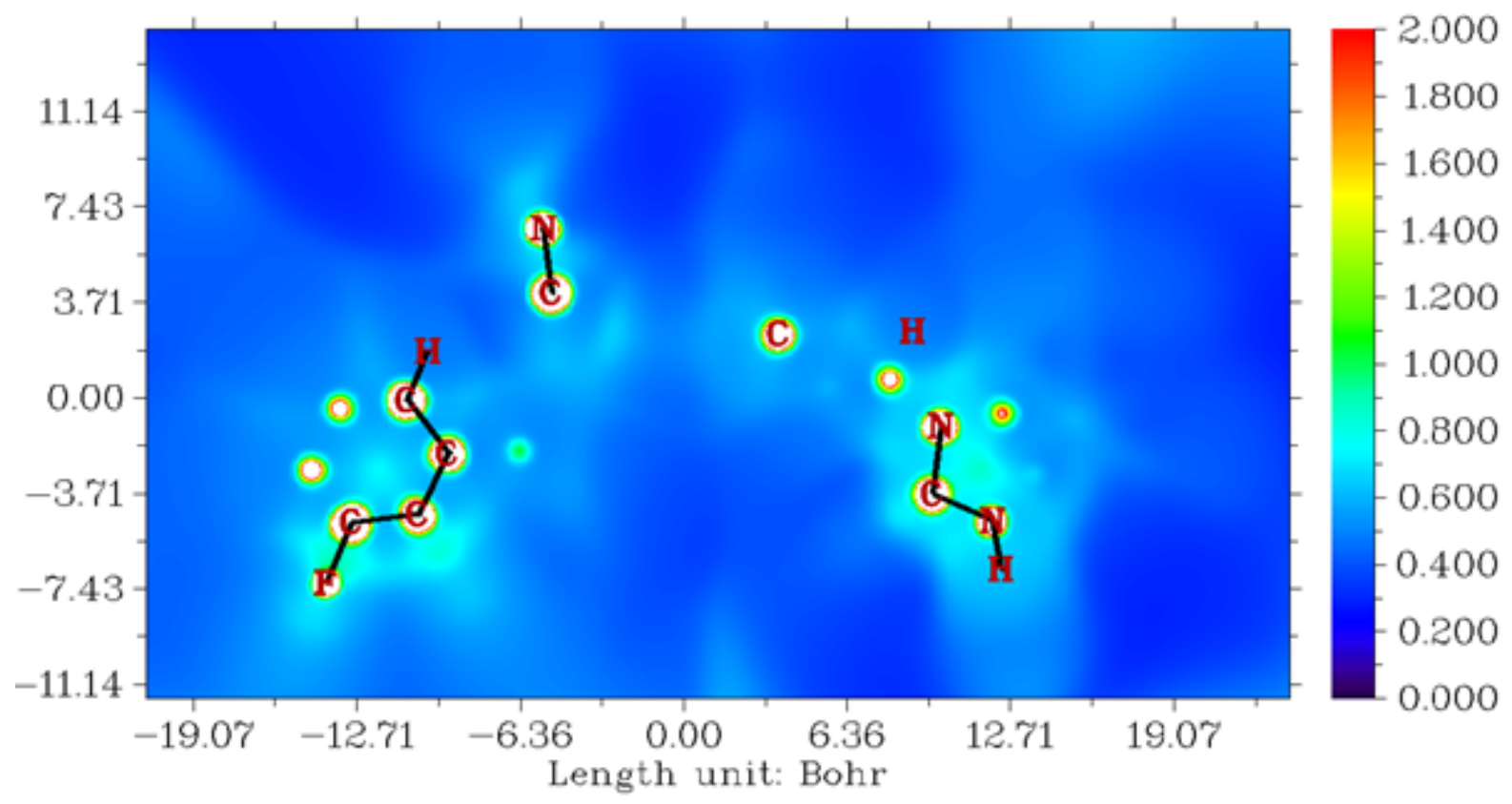

Figure 5

Average localized ionization energy map Rimegepant representing the reactivity centres

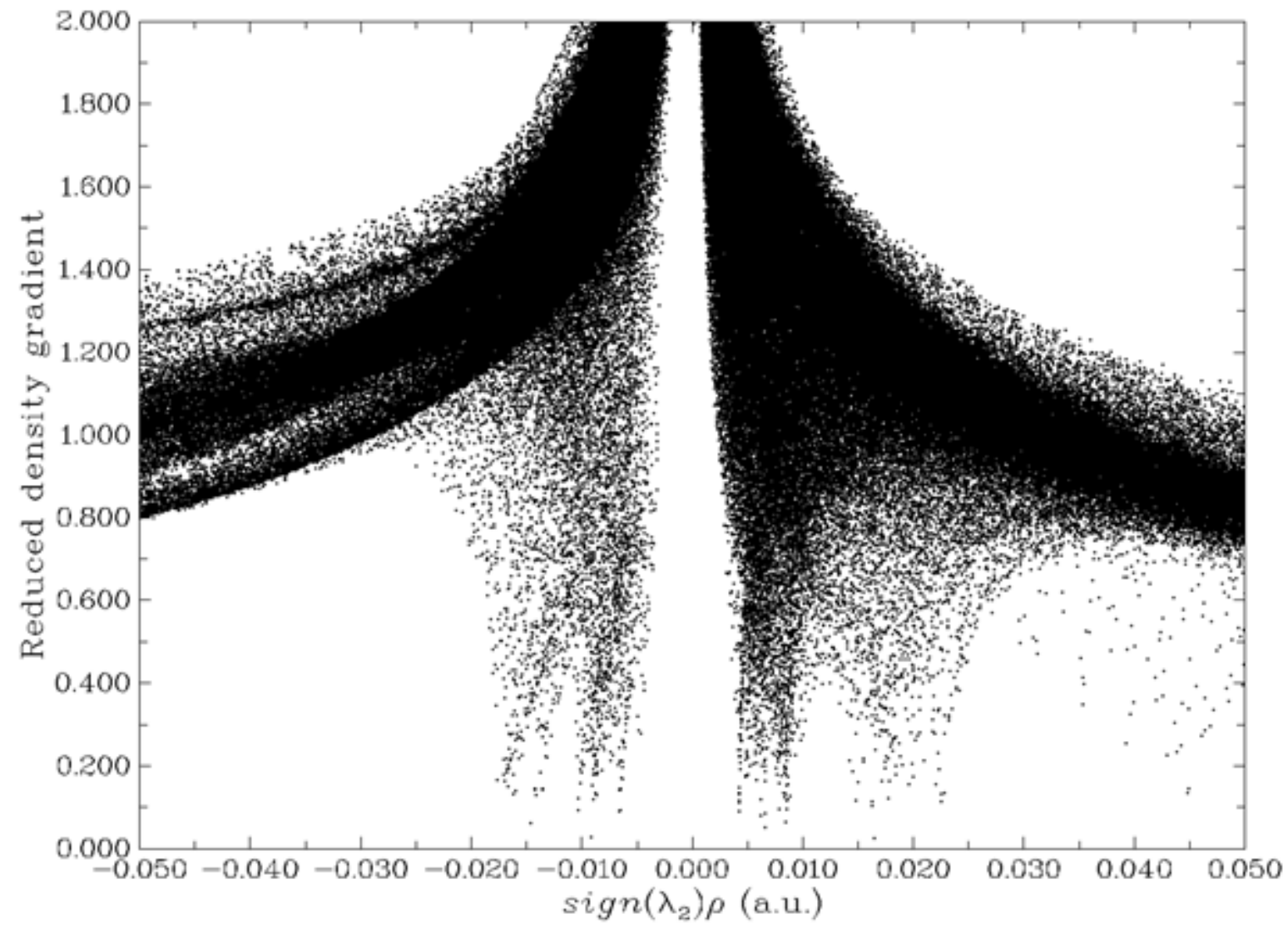

Figure 6 
Non-covalent interactions present in Rimegepant

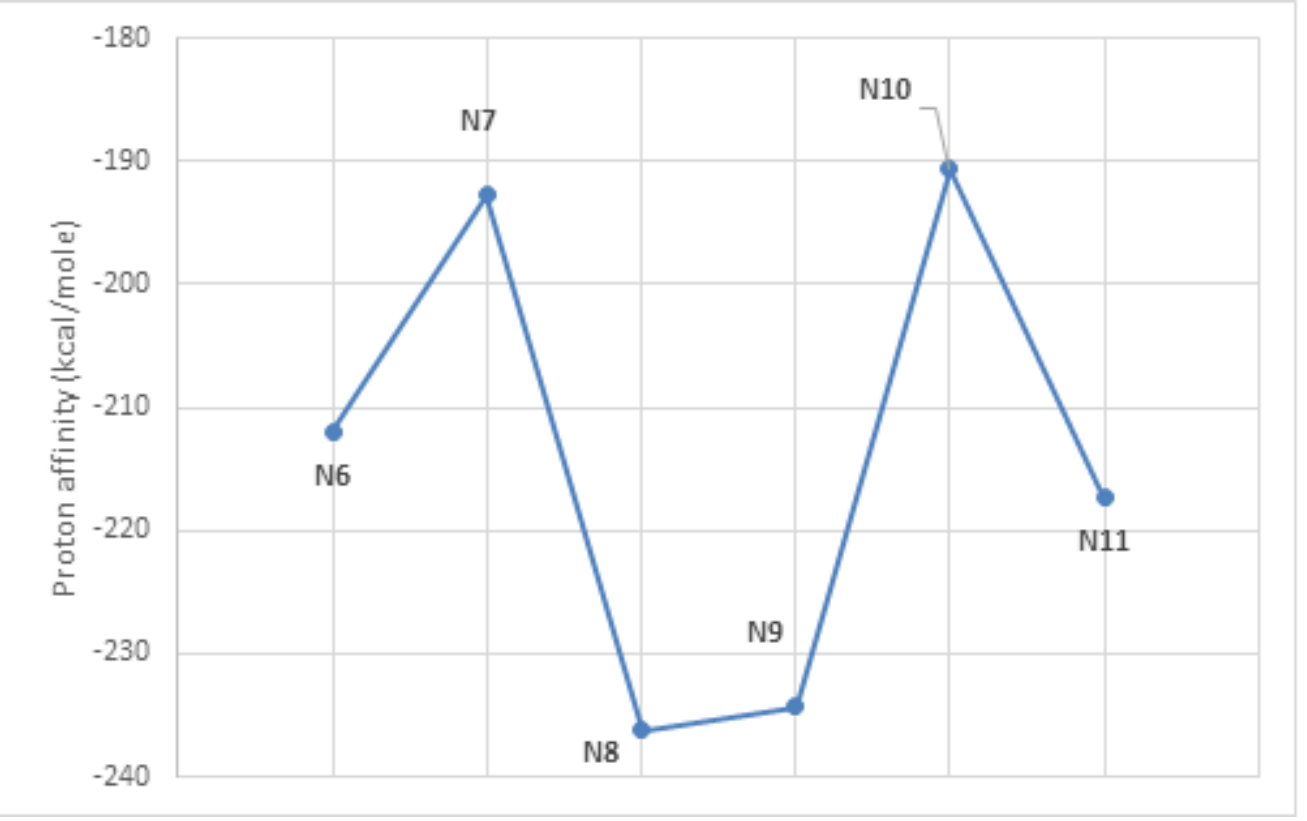

Figure 7

Comparison plot of the proton affinities $(\mathrm{kcal} / \mathrm{mol})$ corresponding to the six different nitrogen atoms of Rimegepant molecule (B3LYP/6-311G+(2d,p)) 


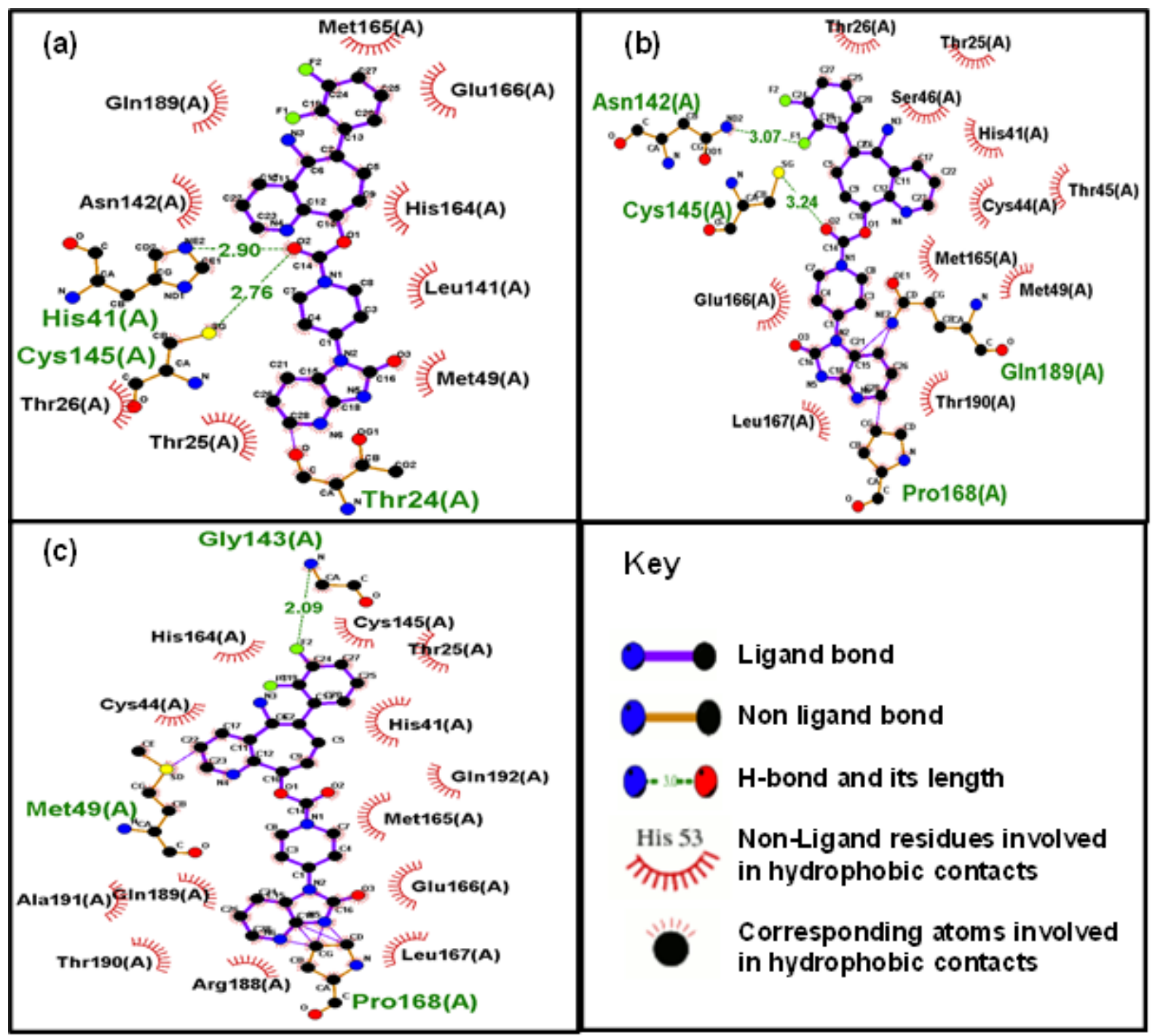

Figure 8

Protein-ligand interactions between Rimegepant and (a) 6LU7,(b) 6M03 and (c) 6W63 proteins as depicted in LigPlot. The bond lengths presented are in angstroms $(\AA)$. 

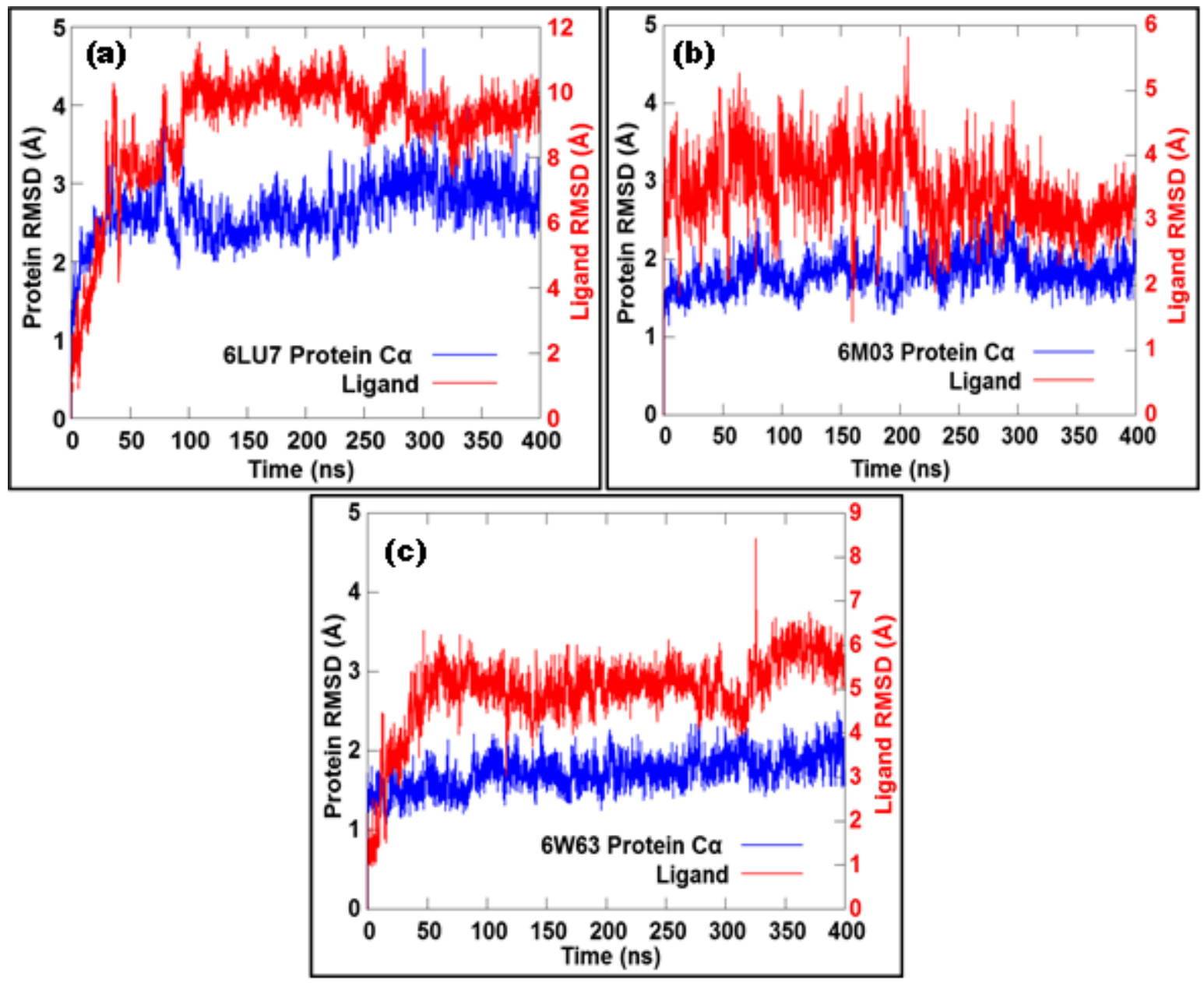

Figure 9

RMSD of the ligand (Rimegepant) with respect to (a) PDB: 6LU7, (b) PDB: 6M03 and (c) PDB: 6W63 over a timeframe of 400 nanoseconds. The RMSD values for the protein models were computed using alpha carbons. 

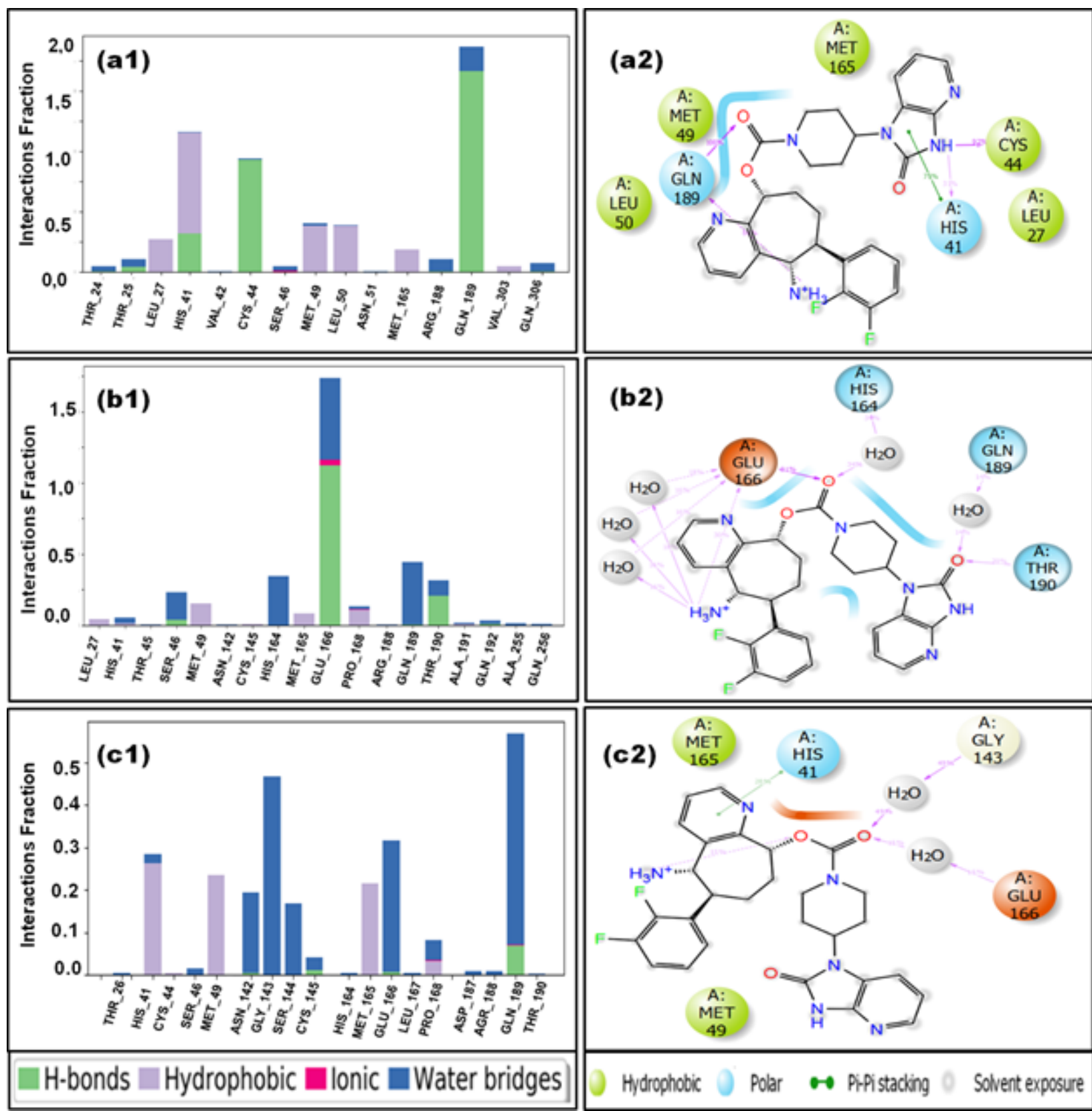

Figure 10

Protein-Ligand interactions (left) and ligand atom interactions (right) with the respective protein receptor residues, (a) 6LU7, (b) 6M03 and (c) 6W63 all docked with Rimegepant (ligand).

\section{Supplementary Files}

This is a list of supplementary files associated with this preprint. Click to download.

- ESIApril11.docx 